УДК $634.8: 631.54$

DOI 10.30679/2219-5335-2020-6-66-123-148

УПРАВЛЕНИЕ УСТОЙЧИВОСТЬЮ АМПЕЛОЦЕНОЗОВ

В УСЛОВИЯХ

АНТРОПОГЕННОЙ

ИНТЕНСИФИКАЦИИ

ПРОИЗВОДСТВА И ИЗМЕНЕНИЙ

КЛИМАТА ЮГА РОССИИ

Петров Валерий Семёнович

д-р с.-х. наук

руководитель научного направления

ведущий научный сотрудник

лаборатории управления

воспроизводством в ампелоценозах

и экосистемах

e-mail: petrov_53@mail.ru

Алейникова Галина Юрьевна

канд. с.-х. наук

заведующая лабораторией управления воспроизводством в ампелоценозах

и экосистемах

Панкин Михаил Иванович

д-р с.-х. наук

ведущий научный сотрудник

лаборатории управления

воспроизводством в ампелоценозах

и экосистемах

e-mail: PankinMI@mail.ru

Руссо Дмитрий Эдуардович

канд. с.-х. наук

заведующий функциональным

научным центром

«Виноградарство и виноделие»

e-mail: dmitriyrusso@yandex.ru

Красильников Александр Андреевич

канд. с.-х. наук

старший научный сотрудник

лаборатории управления

воспроизводством в ампелоценозах

и экосистемах

e-mail: akrasilnikov@yandex.ru
UDC $634.8: 631.54$

DOI 10.30679/2219-5335-2020-6-66-123-148

\section{SUSTAINABILITY CONTROL OF AMPELOCENOSES \\ UNDER CONDITIONS \\ OF ANTHROPOGENIC \\ INTENSIFICATION OF PRODUCTION \\ AND CLIMATE CHANGES \\ IN THE SOUTH OF RUSSIA}

Petrov Valeriy Semionovich

Dr. Sci. Agr.

Head of Scientific direction

Leading Research Associate

of Reproduction Control

in the Ampelocenoses

and Ecological systems Laboratory

e-mail: petrov_53@mail.ru

Aleinikova Galina Yurievna

Cand. Agr. Sci.

Head of Reproduction Control

in the Ampelocenoses

and Ecological systems Laboratory

Pankin Mikhail Ivanovich

Dr. Sci. Agr.

Leading Research Associate

of Reproduction Control

in the Ampelocenoses

and Ecological systems Laboratory

e-mail: PankinMI@mail.ru

Russo Dmitriy Eduardovich

Cand. Agr. Sci.

Head of the Functional

Scientific Center

«Viticulture and winemaking»

e-mail: dmitriyrusso@yandex.ru

Krasilnikov Alexandr Andreevich

Cand. Agr. Sci.

Senior Research Associate

of Reproduction Control

in the Ampelocenoses

and Ecological systems Laboratory

e-mail: akrasilnikov@yandex.ru 
Воробьева Татьяна Николаевна

д-р с.-х. наук, профессор

главный научный сотрудник

e-mail: toksikolog@mail.ru

Федеральное государственное

бюджетное научное учреждение

«Северо-Кавказский федеральный

научный иентр садоводства,

виноградарства, виноделия»,

Краснодар, Россия

Лукьянов Алексей Александрович

канд. с.-х. наук

директор АЗОСВиВ,

ст. научный сотрудник

Анапская зональная опытная станция

виноградарства и виноделия -

филиал Федерального государственного

бюджетного научного учреждения

«Северо-Кавказский федеральный

научныии иентр садоводства,

виноградарства, виноделия»,

Анапа, Россия

Казахмедов Рамидин Эфендиевич

д-р биол. наук

зам. директора по науке

зав. лабораторией биотехнологии, физиологии и продуктов переработки винограда

e-mail: kre_05@mail.ru

\section{Дагестанская селекционная опытная}

станция виноградарства и овощеводства -

филиал Федерального государственного

бюджетного научного учреждения

«Северо-Кавказский федеральный

научный иентр садоводства,

виноградарства, виноделия»,

Дербент, Республика Дагестан, Россия

На основе длительных научных исследований предложены методы эффективного управления устойчивостью ампелоценозов в условиях антропогенной интенсификации производства и погодных аномалий. Исследования выполнены в агроэкологических условиях острого дефицита атмосферных осадков, повышенной солнечной инсоляции
Vorobyova Tatyana Nikolaevna

Dr. Sci. Agr., Professor

Chief Research Associate

e-mail: toksikolog@mail.ru

Federal State Scientific

Budget Institution

«North-Caucasian Federal

Scientific Center of Horticulture,

Viticulture, Winemaking»,

Krasnodar, Russia

Lukyanov Aleksey Aleksandrovich

Cand. Agr. Sci.

Chief of AZESVW,

Senior Research Associate

Anapa Zonal Experimental Station

of Viticulture and Wine-making -

Branch of Federal State

Budget Scientific Institution

«North-Caucasus Federal Scientific

Center of Horticulture,

Viticulture, Wine-making»,

Anapa, Russia

Kazakhmedov Ramidin Efendievich

Dr. Sci. Biol.

Deputy Chief for Science

Head of Biotechnology,

Physiology and Grape Processing

Products Laboratory

e-mail: kre_05@mail.ru

Daghestan Selection Testing

Station of Viticulture and Horticulturebranch of the Federal State

Budgetary Scientific Institution

«North Caucasian Federal

Scientific Center of Horticulture,

Viticulture, Winemaking»,

Derbent, Daghestan Republic, Russia

Based on exhaustive research,

it is proposed the methods for efficient

stability control of ampelocenosis

under the conditions of anthropogenic

intensification of production, and weather

anomalies. The studies were performed

under the agroecological conditions

of acute shortage of rainfall, and high 
и температуры воздуха умеренно континентального климата юга России, в промышленных насаждениях, на наиболее распространенных сортах винограда с использованием современных полевых и лабораторных методов. Для устойчивого виноградарства в Краснодарском крае выделено 5 агроэкологических зон и 47 подзон с использованием цифровых почвенных карт, карт изотерм и изогиет. Каждая выделенная подзона характеризуется однородностью территории по почвам, температурному режиму и атмосферным осадкам и является основой для формирования терруаров и качественного виноделия, а также для оптимизациии зонально ориентированного сортимента и агротехнологий. Предложены оптимизированные схемы, плотность посадки кустов винограда и их нагрузка побегами на примере сорта Рислинг рейнский; режимы некорневого питания растений микроэлементами в сочетании с биологически активными компонентами, в том числе на засоленных почвах. Обоснованы биологизированные технологии обратимости деградационных изменений почвы ампелоценозов на основе энергетического биоматериала. Разработаны методы управления устойчивостью корнесобственных виноградников к карантинному вредителю корневой филлоксере на основе использования физиологически активных соединений. Установлено положительное влияние предлагаемых методов на эффективное использование возобновляемых природных ресурсов (свет, тепло, вода, питание) в продукционном процессе растений винограда. Отмечается повышение уровня реализации потенциала хозяйственной продуктивности растений, улучшение качества винограда и винопродукции.

Применение предлагаемых методов повышает продукционную, агроэкологическую и эдафическую устойчивость ампелоценозов.

Ключевые слова: ВИНОГРАД, ИНТЕНСИФИКАЦИЯ ПРОИЗВОДСТВА, ИЗМЕНЕНИЕ КЛИМАТА, УСТОЙЧИВОСТЬ АМПЕЛОЦЕНОЗОВ solar insolation and air temperature of moderately continental climate of the South of Russia in the industrial plantations with the most wide-spread grape varieties using the modern field and laboratory methods. For sustainable viticulture in the Krasnodar Region 5 agroecological zones and 47 sub-areas are allocated using digital soil maps, maps of isotherms and isohyets. Each subzone is characterized by the uniformity of the site soil, temperature and rainfall and is the basis for the formation of the terroir and quality winemaking as well as for optimization of zonally oriented assortment and technologies. It is proposed the optimized scheme and the planting density of vines, their load by shoots using as a model the Rhine Riesling variety; regime of plant top dressing with minerals in combination with biologically active components, including saline soils. The biological and technology of reversibility of degradation changes in the ampelocenoses soil based on the energy biomaterial is grounded. The methods of stability control of own-rooted vineyards to the quarantine vermin - phylloxera root using the physiologically active substances. The positive influence of the proposed methods for the efficient use of renewable natural resources (light, heat, water, food) in the vine production process is revealed.

The increase in the level of implementation capacities of economic productivity and improving the quality of grapes and vine production is noted. The applying of the proposed methods $i$ ncreased in production, agro-ecological and edaphic stability of ampelocenoses.

Key words: GRAPES, PRODUCTION

INTENSIFICATION, CLIMATE CHANGE, AMPELOCENOSES STABILITY 
Введение. В современных условиях углубления интеграции российской экономики в мировой рынок для обеспечения устойчивости и конкурентоспособности отечественного виноградарства необходим переход на новый уровень агротехнологий. Современная концепция стабильного конкурентоспособного выращивания винограда в стрессовых погодных условиях умеренно континентального климата юга России и антропогенной интенсификации производства основана на формировании адаптивного виноградарства, создании устойчивых саморегулирующихся агроценозов. Эта задача может быть решена при использовании научно обоснованных технических решений на системной основе.

Базовой основой обеспечения комплексной устойчивости ампелоценозов является зонирование агротерриторий, использование возобновляемых природных ресурсов в продукционном процессе, зонально ориентированного размещения насаждений [1-3]. Это направление приобретает еще большую актуальность в условиях антропогенной интенсификации производства и изменения климата [4-7]. Для обеспечения продукционной устойчивости и максимальной реализации потенциала хозяйственной продуктивности винограда важную роль играют сорт-ориентированные технологии, в наибольшей степени реализующие биологический потенциал сортов [8-11].

Высокоэффективным приемом активации синтетических процессов у растений в ампелоценозах является системное применение удобрений нового поколения. Их применение обеспечивает усиление поступления в растения и транспорт нутриентов, активацию метаболических реакций, нормализует физиологические функции, повышает устойчивость растений к температурным стрессам, урожай и качество винограда [12-15].

К числу факторов, негативно влияющих на эдафическую и экологическую устойчивость ампелоценозов, урожайность и качество виноградовинодельческой продукции относится прогрессирующая деградация почвы виноградных насаждений. В ранних работах исследователей, зарубежных - 
Doran J.W., Wilhaei W.W., Power J.F., Heatherly L.G., Elmore C.D. и российских - Тихонравова П.И., Нестерова А.В., Шикула Н.К., Назаренко Г.В., отмечается, что система традиционного земледелия привела к деградации биологической и экологической функций почвенной системы [16-18]. Супрессивность почвы возможно увеличить обогащением ее органическим веществом, богатым различными видами микроорганизмов и элементами питания [19-22].

Засоление почв является растущей проблемой не только в России, но и во всем мире $[23,24]$. Высокая концентрация солей в почвенном растворе оказывает отрицательное воздействие на ростовые процессы и продуктивность растений, нарушая метаболические процессы и снижая эффективность фотосинтеза [25-27].

В современном виноградарстве актуальны проблемы поиска методов повышения устойчивости винограда к филлоксере. В решении данных проблем эффективны физиологически активные соединения (ФАС), в том числе аналоги фитогормонов $[28,29]$. Эндогенные фитогормоны и их синтетические аналоги составляют промежуточное звено между экспрессирующими генами и основными метаболическими центрами растений и находятся в постоянном взаимодействии с ними. Раскрытие законов гормональной регуляции жизнедеятельности растений является актуальной проблемой не только в теории, но и на практике.

Из вышеописанного следует, что научные исследования по устойчивости ампелоценозов в современном виноградарстве большей частью носят разрозненный и незавершенный характер и требуют дальнейшего развития в целях совершенствования агротехнологий.

Целью настоящих исследований является совершенствование и разработка новых методов управления онтогенезом винограда, отвечающих современным требованиям адаптивной, продукционной, эдафической и экологической устойчивости ампелоценозов в условиях усиления антропогенной интенсификации производства и изменений климата юга России. 
Объекты и методы исследований. Экспериментальные исследования выполнены на виноградниках Краснодарского края и Республики Дагестан, аналитические - в лабораториях СКФНЦСВВ, АЗОСВиВ и ДагСОСВиО, в том числе в центре коллективного пользования ФГБНУ СКФНЦСВВ с использованием современных методов и лабораторного оборудования.

Обсуждение результатов. Базовым условием формирования комплексно устойчивых ампелоценозов является зонирование, выделение терруаров, подбор зонально ориентированного сортимента, конструкции насаждений и агротехнологий с учетом ресурсного потенциала территорий и биологических особенностей сортов (рис. 1).

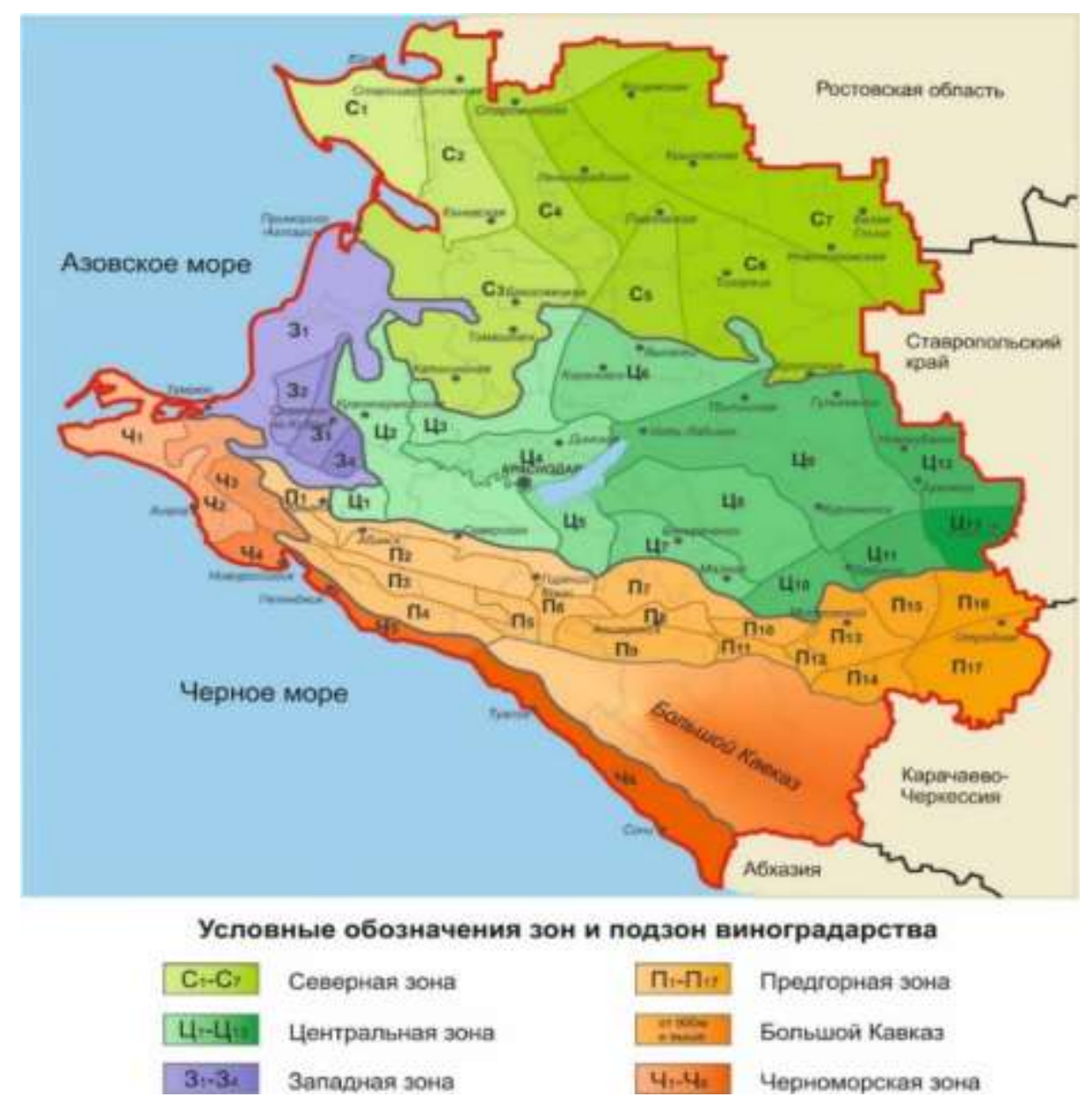

Рис. 1. Карта агроэкологического зонирования территории Краснодарского края 
Плодоводство и виноградарство Юга России № 66(6), 2020 г.

На основе базы метеоданных, оцифрованных почвенной карты, карт изотерм и изогиет, по данным 28 метеостанций Краснодарского края, выделено 5 агроэкологических зон и 47 подзон устойчивого виноградарства. Каждая подзона характеризуется однородностью территории и является основой для формирования терруаров, эффективного использования возобновляемых природных ресурсов в продукционном процессе, повышения уровня реализации потенциала хозяйственной продуктивности винограда и улучшения качества винопродукции. Цифровые параметры выделенных подзон представлены в таблице 1.

Таблица 1 - Почвенно-климатические параметры агроэкологических зон и подзон виноградарства в Краснодарском крае

\begin{tabular}{|c|c|c|c|c|c|c|}
\hline \multirow[b]{2}{*}{$\begin{array}{l}\text { Под- } \\
\text { зоны }\end{array}$} & \multirow[b]{2}{*}{ Преобладающий тип почвы } & \multicolumn{4}{|c|}{ Температура воздуха, ${ }^{\circ} \mathrm{C}$} & \multirow{2}{*}{$\begin{array}{c}\text { Годовая } \\
\text { сумма } \\
\text { осадков, } \\
\text { мм }\end{array}$} \\
\hline & & $\begin{array}{c}\text { среднегодо- } \\
\text { вая }\end{array}$ & $\begin{array}{l}\text { мак- } \\
\text { си- } \\
\text { маль- } \\
\text { ная }\end{array}$ & $\begin{array}{c}\text { мини- } \\
\text { мальная }\end{array}$ & \begin{tabular}{|c|} 
сумма \\
активных \\
темпера- \\
тур
\end{tabular} & \\
\hline 1 & 2 & 3 & 4 & 5 & 6 & 7 \\
\hline \multicolumn{7}{|c|}{ Северная зона } \\
\hline $\mathrm{C}_{1}$ & \multirow{7}{*}{$\begin{array}{l}\text { Черноземы южные и обык- } \\
\text { новенные мицелярно-кар- } \\
\text { бонатные (черноземы глу- } \\
\text { бокие карбонатные) }\end{array}$} & $+11,5 \ldots+12,0$ & +40 & $-25 \ldots-26$ & $3800 \ldots 3850$ & $450-550$ \\
\hline $\mathrm{C}_{2}$ & & $+11,5 \ldots+12,0$ & +40 & $-27 \ldots-28$ & $3700 \ldots 3800$ & $500-650$ \\
\hline $\mathrm{C}_{3}$ & & $+12,0 \ldots+12,5$ & +41 & $-25 \ldots-28$ & $3800 \ldots 3950$ & $550-700$ \\
\hline $\mathrm{C}_{4}$ & & $+11,3 \ldots+12,0$ & +40 & $-28 \ldots-30$ & $3700 \ldots 3850$ & $450-650$ \\
\hline $\mathrm{C}_{5}$ & & $+11,5 \ldots+12,0$ & +42 & $-32 \ldots-33$ & $3700 \ldots 3850$ & $600-700$ \\
\hline $\mathrm{C}_{6}$ & & $+11,5 \ldots+12,0$ & +40 & $-30 \ldots-31$ & $3700 \ldots 3850$ & $500-650$ \\
\hline $\mathrm{C}_{7}$ & & $+11,0 \ldots+11,5$ & +41 & $-30 \ldots-31$ & $3650 \ldots 3700$ & $550-650$ \\
\hline \multicolumn{7}{|c|}{ Центральная зона } \\
\hline$Ц_{1}$ & $\begin{array}{l}\text { Луговые и лугово-черно- } \\
\text { земные }\end{array}$ & $+11,2 \ldots+12,5$ & +39 & $-30 \ldots-31$ & $3750 \ldots 3850$ & $650-750$ \\
\hline$Ц_{2}$ & $\begin{array}{l}\text { Лугово-черноземные } \\
\text { и луговые }\end{array}$ & $+12,0 \ldots+13,0$ & +40 & $-28 \ldots-30$ & $3800 \ldots 4100$ & $600-900$ \\
\hline$\coprod_{3}$ & Черноземы типичные & $+12,0 \ldots+12,5$ & +41 & $-28 \ldots-30$ & $3850 \ldots 4050$ & $650-700$ \\
\hline$\bigsqcup_{4}$ & Черноземы выщелоченные & $+12,5 \ldots+13,0$ & +40 & $-28 \ldots-30$ & $3900 \ldots 4100$ & $700-800$ \\
\hline Ц 5 & Луговые & $+12,0 \ldots+13,0$ & +40 & $-26 \ldots-28$ & $3800 \ldots 4100$ & $800-1000$ \\
\hline$Ц_{6}$ & Черноземы типичные & $+12,0 \ldots+12,5$ & +41 & $-30 \ldots-34$ & $3800 \ldots 4050$ & $650-700$ \\
\hline$Ц_{7}$ & $\begin{array}{l}\text { Черноземы выщелоченные } \\
\text { и лугово-черноземные }\end{array}$ & $+12,0 \ldots+12,5$ & +40 & $-24 \ldots-26$ & $3800 \ldots 3900$ & $750-900$ \\
\hline Ц 8 & $\begin{array}{l}\text { Черноземы выщелоченные } \\
\text { и лугово-черноземные }\end{array}$ & $+11,5 \ldots+12,5$ & +40 & $-25 \ldots-28$ & $3800 \ldots 3900$ & $750-800$ \\
\hline
\end{tabular}


Плодоводство и виноградарство Юга России № 66(6), 2020 г.

\begin{tabular}{|c|c|c|c|c|c|c|}
\hline \multicolumn{7}{|c|}{ Продолжение таблицы } \\
\hline 1 & 2 & 3 & 4 & 5 & 6 & 7 \\
\hline Ц 9 & $\begin{array}{l}\text { Черноземы типичные } \\
\text { и обыкновенные }\end{array}$ & $+11,5 \ldots+12,5$ & +41 & $-28 \ldots-30$ & $3700 \ldots 3800$ & $650-750$ \\
\hline Ц 10 & $\begin{array}{l}\text { Черноземы выщелоченные } \\
\text { и лугово-черноземные }\end{array}$ & $+11,1 \ldots+11,7$ & +40 & $-27 \ldots-28$ & $3600 \ldots 3800$ & $750-900$ \\
\hline Ц 11 & $\begin{array}{l}\text { Черноземы обыкновенные } \\
\text { и типичные }\end{array}$ & $+11,0 \ldots+11,5$ & +40 & $-27 \ldots-30$ & $3500 \ldots 3700$ & $650-750$ \\
\hline Ц 12 & $\begin{array}{l}\text { Черноземы обыкновенные } \\
\text { и луговые }\end{array}$ & $+11,0 \ldots+11,7$ & +41 & $-30 \ldots-31$ & $3700 \ldots 3800$ & $600-650$ \\
\hline Ц 13 & $\begin{array}{l}\text { Луговые и черноземы } \\
\text { обыкновенные }\end{array}$ & $+10,5 \ldots+11,5$ & +41 & $-30 \ldots-31$ & $3500 \ldots 3700$ & $600-650$ \\
\hline \multicolumn{7}{|c|}{ Западная зона } \\
\hline $3_{1}$ & Плавни & $+12,0 \ldots+12,5$ & +40 & $-26 \ldots-30$ & $3800 \ldots 3850$ & $550-700$ \\
\hline $3_{2}$ & Луговые & $+12,0 \ldots+12,5$ & +40 & $-26 \ldots-28$ & $3750 \ldots 3850$ & $550-650$ \\
\hline $3_{3}$ & Луговые & $+12,0 \ldots+12,5$ & +40 & $-28 \ldots-30$ & $3750 \ldots 3800$ & $650-700$ \\
\hline $3_{4}$ & Луговые & $+12,0 \ldots+12,5$ & +40 & $-30 \ldots-32$ & $3750 \ldots 3850$ & $650-700$ \\
\hline \multicolumn{7}{|c|}{ Предгорная зона } \\
\hline$\Pi_{1}$ & $\begin{array}{l}\text { Серые лесные и черноземы } \\
\text { выщелоченные }\end{array}$ & $+12,2 \ldots+13,0$ & +40 & $-28 \ldots-31$ & $3750 \ldots 3950$ & $600-1100$ \\
\hline$\Pi_{2}$ & Бурые горнолесные & $+12,5 \ldots+13,0$ & +40 & $-28 \ldots-30$ & $3800 \ldots 3950$ & $700-1100$ \\
\hline$\Pi_{3}$ & Бурые горнолесные & $+12,5 \ldots+13,0$ & +40 & $-26 \ldots-28$ & $3900 \ldots 4000$ & $800-1100$ \\
\hline$\Pi_{4}$ & $\begin{array}{l}\text { Бурые горнолесные и } \\
\text { дерново-кабонатные }\end{array}$ & $+13,0 \ldots+13,5$ & +40 & $-23 \ldots-26$ & $3900 \ldots 4100$ & $800-1150$ \\
\hline$\Pi 5$ & Дерново- карбонатные & $+12,0 \ldots+13,0$ & +40 & $-26 \ldots-30$ & $3900 \ldots 4100$ & $\begin{array}{l}1000- \\
1200\end{array}$ \\
\hline$\Pi_{6}$ & $\begin{array}{l}\text { Бурые горнолесные и } \\
\text { дерново-кабонатные }\end{array}$ & $+11,5 \ldots+12,5$ & +40 & $-26 \ldots-30$ & $3700 \ldots 4000$ & $\begin{array}{l}1000- \\
1200\end{array}$ \\
\hline$\Pi_{7}$ & Серые лесные и луговые & $+11,5 \ldots+12,0$ & +41 & $-24 \ldots-28$ & $3700 \ldots 3850$ & $900-1200$ \\
\hline$\Pi 8$ & Дерново-карбонатные & 2,0 & +40 & -26 & 3600 & $\begin{array}{l}1000- \\
1500\end{array}$ \\
\hline П 9 & Бурые горнолесные & $+10,5 \ldots+11,5$ & +40 & $-28 \ldots-30$ & $3400 \ldots 3600$ & $\begin{array}{l}1100- \\
1700\end{array}$ \\
\hline$\Pi_{10}$ & Серые лесные & $+10,5 \ldots+11,5$ & +40 & $-28 \ldots-30$ & $3500 \ldots 3700$ & $800-1000$ \\
\hline$\Pi_{11}$ & Дерново-карбонатные & $+10,0 \ldots+11,0$ & +39 & $-28 \ldots-30$ & $3400 \ldots 3600$ & $900-1100$ \\
\hline$\Pi_{12}$ & Серые лесные & $+9,5 \ldots+10,5$ & +39 & $-28 \ldots-30$ & $3300 \ldots 3500$ & $800-900$ \\
\hline$\Pi_{13}$ & $\begin{array}{l}\text { Черноземы выщелоченные } \\
\text { и луговые }\end{array}$ & $+9,5 \ldots+11,0$ & +39 & $-28 \ldots-30$ & $3300 \ldots 3500$ & $750-850$ \\
\hline$\Pi_{14}$ & $\begin{array}{l}\text { Дерново-карбонатные } \\
\text { и луговые }\end{array}$ & $+9,3 \ldots+10,0$ & +39 & $-30 \ldots-32$ & $3100 \ldots 3300$ & $750-900$ \\
\hline$\Pi_{15}$ & Черноземы типичные & $+10,0 \ldots+11,0$ & +39 & $-28 \ldots-30$ & $3300 \ldots 3500$ & $700-750$ \\
\hline$\Pi_{16}$ & $\begin{array}{l}\text { Черноземы обыкновенные } \\
\text { и луговые }\end{array}$ & $+10,0 \ldots+10,5$ & +40 & $-30 \ldots-32$ & $3300 \ldots 3500$ & $650-700$ \\
\hline$\Pi_{17}$ & $\begin{array}{l}\text { Черноземы обыкновенные, } \\
\text { выщелоченные и луговые }\end{array}$ & $+9,3 \ldots+10,0$ & +39 & $-30 \ldots-32$ & $3100 \ldots 3300$ & $650-750$ \\
\hline \multicolumn{7}{|c|}{ Черноморская зона } \\
\hline $\mathbf{Y}_{1}$ & Черноземы южные & $+12,4 \ldots+13,0$ & +38 & $-22 \ldots-24$ & $3800 \ldots 3950$ & $500-550$ \\
\hline $\mathbf{Y}_{2}$ & $\begin{array}{l}\text { Черноземы обыкновенные, } \\
\text { выщелоченные и луговые }\end{array}$ & $+12,5 \ldots+13,5$ & +38 & $-24 \ldots-26$ & $3800 \ldots 4000$ & $550-600$ \\
\hline $\mathbf{Y}_{3}$ & Дерново-карбонатные & $+12,5 \ldots+13,0$ & +39 & $-24 \ldots-28$ & $3800 \ldots 3900$ & $550-700$ \\
\hline $\mathbf{Y}_{4}$ & Дерново-карбонатные & $+13,0 \ldots+13,5$ & +39 & $-22 \ldots-26$ & $3900 \ldots 4000$ & $700-900$ \\
\hline $\mathbf{Y}_{5}$ & Дерново-карбонатные & $+13,5 \ldots+14,0$ & +39 & $-22 \ldots-24$ & $4000 \ldots 4100$ & $900-1150$ \\
\hline$\Psi_{6}$ & $\begin{array}{l}\text { Дерново-карбонатные } \\
\text { и желтоземы }\end{array}$ & $+13,5 \ldots+15,0$ & +39 & $-9 \ldots-22$ & $4100 \ldots 4400$ & $\begin{array}{l}1150- \\
1750\end{array}$ \\
\hline
\end{tabular}


Важным условием эффективного использования возобновляемых природных ресурсов агротерриторий в продукционном процессе винограда и обеспечения устойчивости ампелоценозов является подбор и размещение сортов. При формировании сортимента приоритетом должны обладать автохтонные и отечественные сорта и клоны, используемые по месту их происхождения, а также интродуцированные всемирно признанные. Сорта в местах их происхождения наиболее полно реализуют свои положительные хозяйственно ценные и биологические признаки, обеспечивают адаптивную, продукционную и экологическую устойчивость (рис. 2).
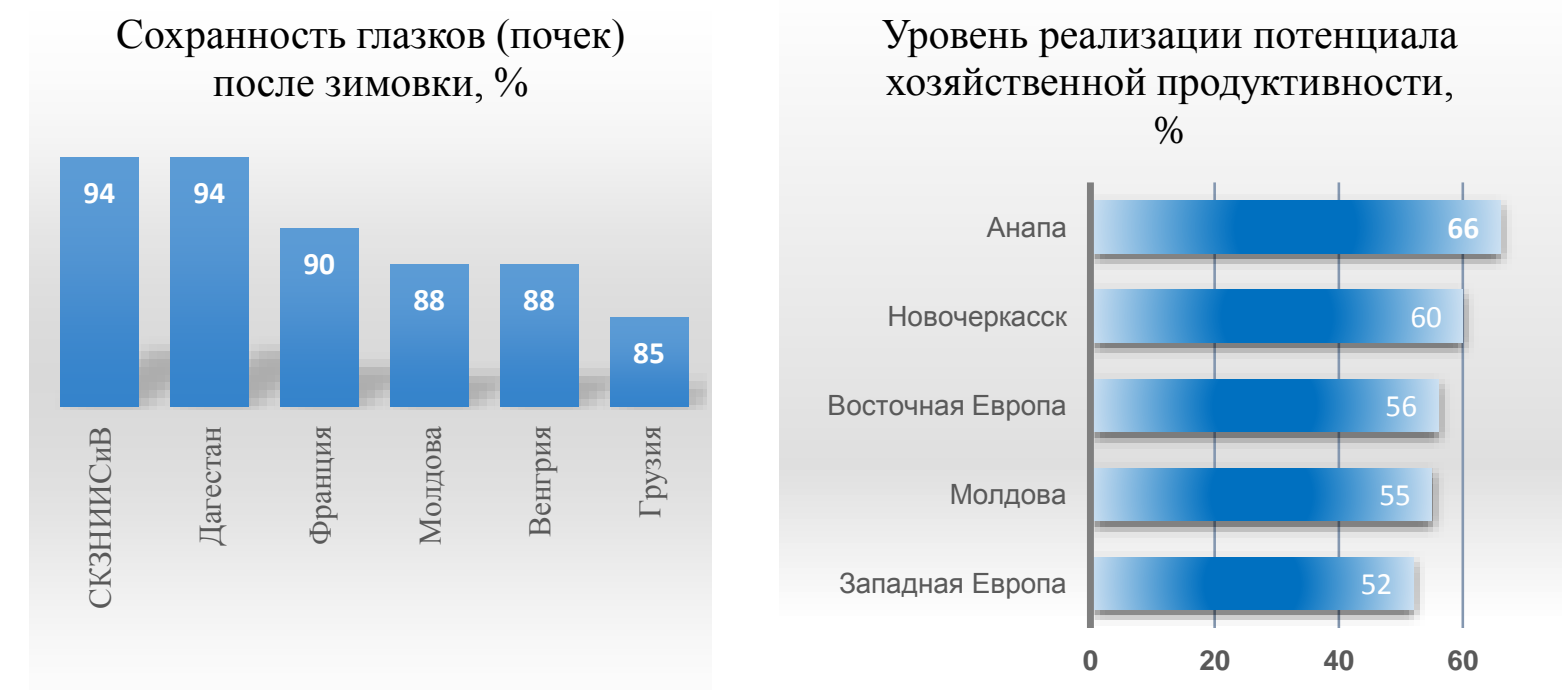

Рис. 2. Реализация хозяйственно ценных признаков винограда в агроэкологических условиях юга России в зависимости от происхождения сортов, 2007-2010 гг.

Сорта и клоны, рекомендуемые для формирования устойчивых ампелоценозов, должны обладать повышенными значениями ценных признаков по адаптивности, продуктивности и качеству винограда, устойчивости к грибным заболеваниям, отличаться устойчивостью к морозам, $-22{ }^{\circ} \mathrm{C} \ldots-31^{\circ} \mathrm{C}$ (табл. 2). 
Плодоводство и виноградарство Юга России № 66(6), 2020 г.

Таблица 2 - Сорта и клоны для создания устойчивых насаждений винограда в агроэкологических условиях юга России

\begin{tabular}{|c|c|c|c|c|c|c|c|c|c|c|}
\hline \multirow[b]{2}{*}{ Сорт } & \multirow[b]{2}{*}{$\begin{array}{c}\text { Размер } \\
\text { грозди, } \\
\Gamma\end{array}$} & \multicolumn{3}{|c|}{ Ягода } & \multirow{2}{*}{ 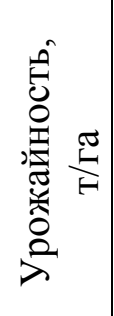 } & \multirow{2}{*}{ 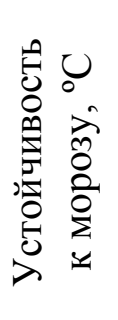 } & \multicolumn{4}{|c|}{$\begin{array}{c}\text { Восприимчивость, } \\
\text { балл } \\
\end{array}$} \\
\hline & & 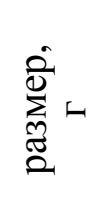 & $\begin{array}{l}\breve{\mathscr{U}} \\
\stackrel{\mathscr{G}}{G}\end{array}$ & 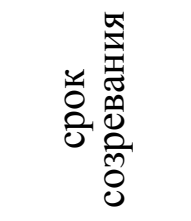 & & & 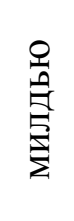 & $\sum_{0}^{\sum_{0}^{5}}$ & 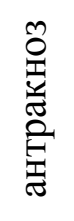 & 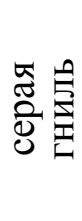 \\
\hline 1 & 3 & 4 & 5 & 6 & 7 & 8 & 9 & 10 & 11 & 12 \\
\hline \multicolumn{11}{|c|}{ Отечественные } \\
\hline \multicolumn{11}{|c|}{ Столовые } \\
\hline Баклановский & 850 & 6 & белый & $\begin{array}{c}\text { сверхран- } \\
\text { ний }\end{array}$ & $12-14$ & -25 & 2 & 2 & 2 & 2 \\
\hline Боготяновский & $\begin{array}{l}800- \\
1100\end{array}$ & & белый & $\begin{array}{l}\text { сверхран- } \\
\text { ний }\end{array}$ & & -23 & 2 & 2 & 2 & 2 \\
\hline Лотос & 380 & $3-4$ & розовый & ранний & $12-14$ & -22 & 2 & 2 & 2 & 2 \\
\hline $\begin{array}{l}\text { Надежда } \\
\text { АЗОС }\end{array}$ & 500 & $6-7$ & черный & ранний & $8-15$ & -25 & 2 & 2 & 1 & 2 \\
\hline Низина & 700 & 12 & $\begin{array}{c}\text { красно- } \\
\text { фиолето- } \\
\text { вый } \\
\end{array}$ & ранний & 12 & -22 & 3 & 3 & 2 & 2 \\
\hline Первозванный & 1000 & 12 & белый & $\begin{array}{c}\text { сверхран- } \\
\text { ний }\end{array}$ & 12 & -22 & 2 & 2 & 2 & 2 \\
\hline Романтика & 700 & 7 & $\begin{array}{c}\text { темно- } \\
\text { фиолето- } \\
\text { вый } \\
\end{array}$ & средний & $12-14$ & -26 & 2 & 2 & 2 & 2 \\
\hline $\begin{array}{l}\text { Фея } \\
\text { (Людмила) }\end{array}$ & 800 & 10 & белый & ранний & $10-12$ & -25 & 2 & 2 & 2 & 2 \\
\hline \multicolumn{11}{|c|}{ Технические } \\
\hline Алькор & $180-220$ & $1,5-2$ & красный & $\begin{array}{l}\text { средне- } \\
\text { поздний }\end{array}$ & 15 & -22 & 2 & 4 & 1 & 2 \\
\hline Антарис & $220-350$ & $2-3$ & красный & средний & $12-13$ & -22 & 2 & 2 & 1 & 2 \\
\hline Бархатный & 260 & $2-3$ & $\begin{array}{c}\text { желто-зе- } \\
\text { леный }\end{array}$ & $\begin{array}{l}\text { средне-- } \\
\text { поздний }\end{array}$ & $14-18$ & -18 & $3-4$ & $3-4$ & 1 & $3-4$ \\
\hline Бейсуг & $260-350$ & $2-3$ & белый & $\begin{array}{l}\text { средне-- } \\
\text { поздний }\end{array}$ & 17 & -22 & 4 & 2 & 2 & 4 \\
\hline Варваровский & 260 & $2-3$ & белый & средний & $11-12$ & -27 & 4 & 2 & 2 & 2 \\
\hline Владимир & $150-160$ & $2-3$ & красный & средний & $12-13$ & -27 & 2 & 2 & 1 & 1 \\
\hline Гранатовый & 200 & $2-3$ & $\begin{array}{c}\text { темно-си- } \\
\text { ний } \\
\end{array}$ & поздний & $12-14$ & -22 & 2 & 2 & 1 & 1 \\
\hline Дмитрий & $230-240$ & $2-3$ & красный & поздний & $14-15$ & -25 & 1 & 2 & 1 & 1 \\
\hline Достойный & 240 & $2-3$ & красный & $\begin{array}{l}\text { средне- } \\
\text { поздний }\end{array}$ & 11-13 & -27 & 4 & 4 & 2 & 2 \\
\hline Каберне АЗОС & $250-300$ & $2-3$ & красный & $\begin{array}{l}\text { средне- } \\
\text { поздний }\end{array}$ & $12-13$ & -26 & 2 & 2 & 1 & 2 \\
\hline $\begin{array}{l}\text { Каберне } \\
\text { Кубани }\end{array}$ & 275 & $2-3$ & красный & средний & 12 & -24 & 1 & 1 & 1 & 2 \\
\hline $\begin{array}{l}\text { Каберне } \\
\text { Тамани }\end{array}$ & 195 & $2-3$ & красный & $\begin{array}{l}\text { средне- } \\
\text { поздний }\end{array}$ & 12 & -24 & 1 & 1 & 1 & 2 \\
\hline $\begin{array}{l}\text { Красностоп } \\
\text { АЗОС }\end{array}$ & $120-130$ & $2-3$ & красный & ранний & 12 & -25 & 2 & 2 & 2 & 4 \\
\hline Курчанский & $170-185$ & $2-3$ & красный & $\begin{array}{l}\text { средне- } \\
\text { поздний }\end{array}$ & $12-13$ & -27 & 2 & 2 & 1 & 1 \\
\hline
\end{tabular}


Продолжение таблицы

\begin{tabular}{|c|c|c|c|c|c|c|c|c|c|c|}
\hline 1 & 3 & 4 & 5 & 6 & 7 & 8 & 9 & 10 & 11 & 12 \\
\hline Мицар & $220-350$ & $2-3$ & черный & средний & $12-13$ & -22 & 2 & 2 & 1 & 2 \\
\hline $\begin{array}{l}\text { Мускат } \\
\text { натухаевский }\end{array}$ & 160 & $1,5-2$ & белый & средний & 10 & -25 & 1 & 2 & 2 & 1 \\
\hline $\begin{array}{l}\text { Первенец } \\
\text { Магарача }\end{array}$ & 170 & 1,8 & белый & поздний & $11-13$ & -25 & 2 & 2 & 2 & \\
\hline Платовский & 212 & 2 & белый & $\begin{array}{c}\text { очень } \\
\text { ранний }\end{array}$ & & -29 & 2 & 2 & 1 & 2 \\
\hline $\begin{array}{l}\text { Рислинг } \\
\text { Черноморец }\end{array}$ & 230 & $1,5-2$ & белый & средний & & -24 & 4 & 3 & 3 & 3 \\
\hline Рубин АЗОС & 200 & $2-3$ & красный & $\begin{array}{l}\text { средне- } \\
\text { поздний }\end{array}$ & $11-12$ & -22 & 4 & 2 & 2 & 4 \\
\hline $\begin{array}{l}\text { Саперави } \\
\text { Черноморское }\end{array}$ & 110 & & красный & $\begin{array}{l}\text { средне- } \\
\text { поздний }\end{array}$ & $11-12$ & -24 & 1 & 1 & 1 & 2 \\
\hline $\begin{array}{l}\text { Шардоне } \\
\text { Мильстрим }\end{array}$ & 130 & 1,3 & белый & средний & $10-11$ & -22 & 2 & 4 & 2 & 2 \\
\hline $\begin{array}{l}\text { Цитронный } \\
\text { Магарача }\end{array}$ & $300-400$ & 2 & $\begin{array}{c}\text { зелено- } \\
\text { вато-жел- } \\
\text { тая }\end{array}$ & $\begin{array}{c}\text { раннесред- } \\
\text { ний }\end{array}$ & $15-20$ & -25 & 2 & 2 & 2 & 2 \\
\hline \multicolumn{11}{|c|}{ Интродуцированные, всемирно признанные } \\
\hline \multicolumn{11}{|c|}{ Столовые } \\
\hline Августин & $400-500$ & $4-5$ & белый & ранний & $12-14$ & -22 & 2 & 2 & 4 & 2 \\
\hline $\begin{array}{l}\text { Кишмиш } \\
\text { Запорожский }\end{array}$ & $600-90$ & $2-2,5$ & $\begin{array}{c}\text { темно- } \\
\text { красно- } \\
\text { фиолето- } \\
\text { вый } \\
\end{array}$ & $\begin{array}{c}\text { сверхран- } \\
\text { ний }\end{array}$ & $11-12$ & -24 & 4 & 2 & 2 & 2 \\
\hline Молдова & $385-600$ & 6 & черный & $\begin{array}{l}\text { средне- } \\
\text { поздний }\end{array}$ & $12-15$ & -23 & 2 & 4 & 4 & 2 \\
\hline $\begin{array}{l}\text { Подарок } \\
\text { Запорожью }\end{array}$ & $600-900$ & $10-12$ & белый & ранний & $12-14$ & -22 & 2 & & 1 & 2 \\
\hline Загадка & $500-700$ & 6 & белый & средний & $11-12$ & -24 & 2 & 2 & 2 & 2 \\
\hline \multicolumn{11}{|c|}{ Технические } \\
\hline $\begin{array}{l}\text { Каберне - } \\
\text { Совиньон }\end{array}$ & 75 & 1,2 & черный & $\begin{array}{l}\text { средне- } \\
\text { поздний }\end{array}$ & $10-12$ & -22 & 4 & 2 & 1 & \\
\hline $\begin{array}{l}\text { Ливадийский } \\
\text { черный }\end{array}$ & 250 & 2 & красный & $\begin{array}{c}\text { раннесред- } \\
\text { ний } \\
\end{array}$ & $11-15$ & -25 & 2 & 2 & 2 & 2 \\
\hline Мерло & $120-150$ & 1,4 & черный & поздний & & -22 & 4 & 2 & 1 & \\
\hline $\begin{array}{l}\text { Мцване } \\
\text { кахетинский }\end{array}$ & $120-200$ & $1,5-2$ & белый & $\begin{array}{l}\text { средне- } \\
\text { поздний }\end{array}$ & $6-8$ & -22 & 2 & 2 & 2 & 2 \\
\hline Пино нуар & $80-120$ & 1,3 & синий & ранний & $6-9$ & & & & & \\
\hline $\begin{array}{l}\text { Рислинг } \\
\text { рейнский }\end{array}$ & $80-100$ & 1,4 & белый & средний & $11-12$ & -22 & 4 & 2 & 1 & \\
\hline Саперави & 110 & 4 & красный & поздний & 11 & -22 & 4 & 4 & 1 & 2 \\
\hline Совиньон & 120 & 1,5 & белый & средний & $10-11$ & -22 & 4 & 2 & 1 & 4 \\
\hline
\end{tabular}

Для наиболее полной реализации ценных признаков, а также обеспечения устойчивости ампелоценозов у каждого генотипа винограда должна быть своя сортовая агротехнология, включая создание оптимальной конструкции насаждений винограда, оптимизацию регламентов формирования 
Плодоводство и виноградарство Юга России № 66(6), 2020 г.

и ведения кустов. Сортовая агротехнология позволяет эффективно управлять продукционной устойчивостью ампелоценозов. Это хорошо видно по влиянию схемы и плотности посадки кустов в насаждениях и их нагрузки побегами на продуктивность и качественные показатели винограда и вина в агроэкологических условиях Черноморской зоны (г.-к. Анапа) на сорте винограда Рислинг рейнский.

Исследования показали, что в условиях черноморской агроэкологической зоны виноградарства при повышенной солнечной инсоляции и недостаточной влагообеспеченности продуктивность и качество винограда и винопродукции из сорта Рислинг рейнский находится в тесной зависимости от схемы посадки и плотности насаждений. Из 9 изучаемых вариантов наибольшая урожайность наблюдалась на виноградниках со схемой посадки 3,0×1,0-2,0 м при плотности насаждений 1667-3333 шт./га (табл. 3).

Таблица 3 - Урожайность винограда сорта Рислинг рейнский на участках с разной схемой и плотностью посадки кустов, 2015-2018 гг.

\begin{tabular}{|c|c|c|c|c|c|c|}
\hline $\begin{array}{c}\text { Схема } \\
\text { посадки } \\
\text { кустов, м }\end{array}$ & $\begin{array}{c}\text { Плотность } \\
\text { посадки } \\
\text { кустов, } \\
\text { шт./га }\end{array}$ & $\begin{array}{c}\text { Количе- } \\
\text { ство } \\
\text { побегов, } \\
\text { шт./куст }\end{array}$ & $\begin{array}{c}\text { Количе- } \\
\text { ство } \\
\text { гроздей, } \\
\text { шт./куст }\end{array}$ & $\begin{array}{c}\text { Масса } \\
\text { грозди, } \\
\text { г }\end{array}$ & $\begin{array}{c}\text { Урожай } \\
\text { винограда, } \\
\text { кг/куст }\end{array}$ & $\begin{array}{c}\text { Урожай- } \\
\text { ность } \\
\text { винограда, } \\
\text { т/га }\end{array}$ \\
\hline $3,5 \times 2,0$ & 1428 & 33 & 54 & 88,80 & 4,96 & 6,97 \\
\hline $3,5 \times 1,5$ & 1905 & 26 & 46 & 86,68 & 3,90 & 7,92 \\
\hline $3,5 \times 1,0$ & 2857 & 18 & 37 & 97,44 & 3,31 & 9,40 \\
\hline $3,0 \times 2,0$ & 1667 & 30 & 59 & 102,60 & 6,07 & 10,29 \\
\hline $3,0 \times 1,5$ & 2222 & 23 & 51 & 108,83 & 5,39 & 11,97 \\
\hline $3,0 \times 1,0$ & 3333 & 15 & 36 & 105,88 & 3,79 & 12,65 \\
\hline $2,5 \times 2,0$ & 2000 & 25 & 51 & 89,40 & 4,47 & 8,93 \\
\hline $2,5 \times 1,5$ & 2667 & 20 & 39 & 95,33 & 3,57 & 9,52 \\
\hline $2,5 \times 1,0$ & 4000 & 14 & 28 & 84,03 & 2,30 & 9,09 \\
\hline
\end{tabular}

По заключению дегустационной комиссии, образцы столовых сухих виноматериалов Рислинг рейнский урожая 2016 и 2017 годов были наилучшими из винограда при схеме посадки 3,0×1,0 м. Они отличались ярким сортовым ароматом с цитронными тонами, полным развитым вкусом с гармоничной кислотностью (рис. 3). 


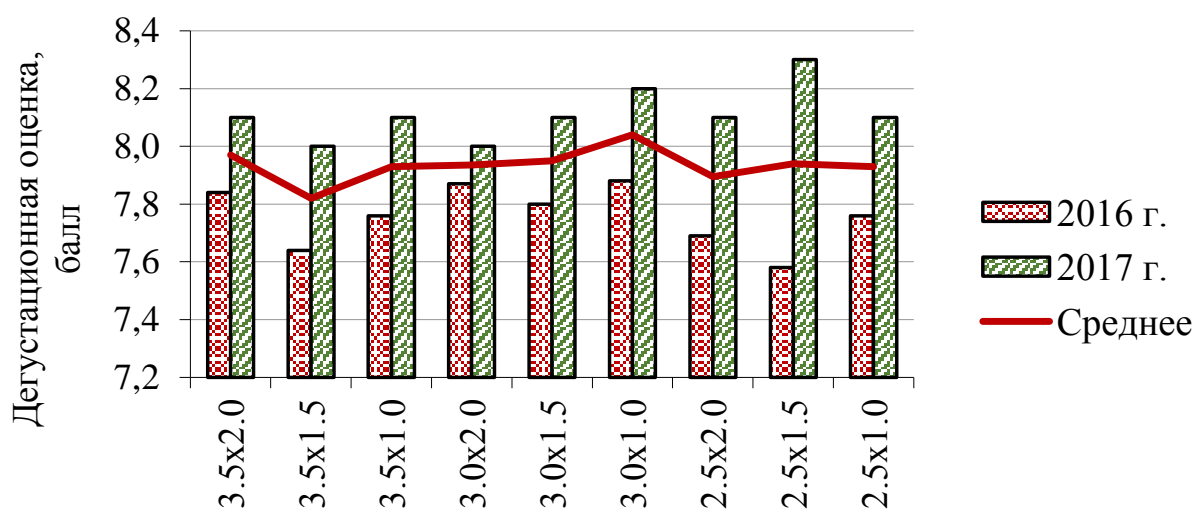

Рис. 3. Дегустационная оценка опытных виноматериалов из винограда сорта Рислинг рейнский

Существенное влияние на ростовые процессы и продуктивность винограда оказывает нагрузка кустов побегами. По данным таблицы 4, скорость роста побегов была прямо пропорциональна увеличению плотности насаждений и обратно пропорциональна увеличению нагрузки кустов побегами. Влияния плотности и схемы посадки кустов на фотосинтетический потенциал растений не установлено. Вместе с тем проявляется закономерность увеличения фотосинтетического потенциала с увеличением нагрузки кустов.

Наибольший фотосинтетический потенциал был при наибольшей нагрузке кустов побегами (60-70 тыс. шт./га) во всех вариантах с разной плотностью и схемой посадки кустов. Количество гроздей увеличивалось пропорционально увеличению плотности насаждений и нагрузки кустов. Средняя масса гроздей имела обратную зависимость: увеличивалась по мере уменьшения плотности насаждений и нагрузки кустов побегами. Урожайность винограда была наибольшей при нагрузке 50 тыс. шт./га побегов, независимо от плотности и схемы посадки. Массовая концентрация сахаров была 19,1-20,2 г/100 $\mathrm{cm}^{3}$, титруемая кислотность - 7,1-8,3 г/дм³.

Эффективное управление устойчивостью ампелоценозов достигается при применении некорневых обработок. В весенне-летний период рассматривали интенсивность ростовых процессов растений винограда в качестве критерия устойчивости к абиотическим стресс факторам зимнего периода 
Плодоводство и виноградарство Юга России № 66(6), 2020 г.

на примере сортов Мерло (ООО «Абрау Дюрсо») и Августин (АФ «Южная»). У винограда Мерло в среднем за 2016-2019 гг. количество плодоносных побегов на фоне некорневых обработок было выше на 7,4 \% по сравнению с контролем без некорневых обработок и составляло в среднем 34 шт./куст. У столового сорта Августин при некорневых обработках количество побегов ежегодно превышало таковое в контрольном варианте на 8,1-14,3\%, что характеризует высокий уровень отзывчивости растений этого сорта на улучшение режима питания.

Таблица 4 - Влияние схемы, плотности посадки и нагрузки кустов побегами на ростовые процессы и продуктивность винограда, г. Анапа, 2019 г.

\begin{tabular}{|c|c|c|c|c|c|c|c|c|c|}
\hline \multirow[b]{2}{*}{ 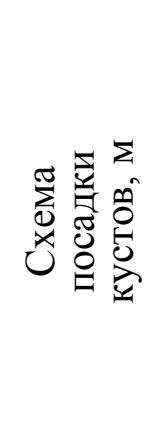 } & \multirow{2}{*}{ 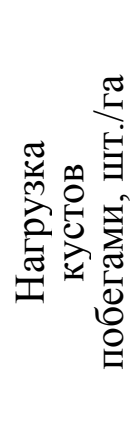 } & \multirow{2}{*}{ 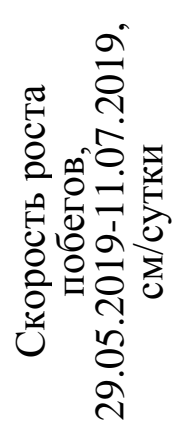 } & \multirow{2}{*}{ 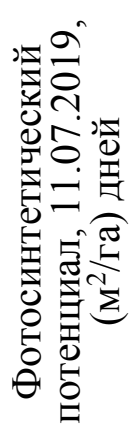 } & \multirow{2}{*}{ 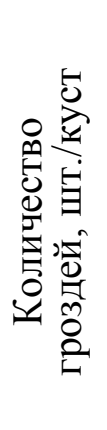 } & \multirow[b]{2}{*}{ 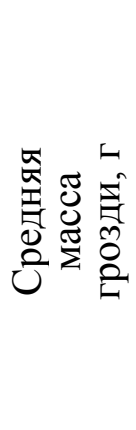 } & \multicolumn{2}{|c|}{ Урожай } & \multicolumn{2}{|c|}{$\begin{array}{c}\text { Массовая } \\
\text { концентрация }\end{array}$} \\
\hline & & & & & & $\sum_{\frac{5}{2}}^{5}$ & $\underset{H}{\stackrel{\pi}{H}}$ & 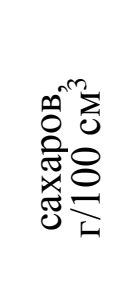 & 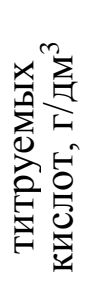 \\
\hline \multirow{4}{*}{$3,0 \times 2,0$} & 40000 & 3,5 & 21734 & 48 & 137,4 & 6,6 & 9,9 & 19,6 & 7,5 \\
\hline & 50000 & 3,1 & 19643 & 62 & 136,2 & 8,4 & 12,7 & 19,6 & 7,5 \\
\hline & 60000 & 2,3 & 22472 & 65 & 102,3 & 6,7 & 10,0 & 17,4 & 8,7 \\
\hline & 70000 & 2,7 & 25354 & 81 & 96,8 & 8,4 & 12,6 & 18,0 & 8,4 \\
\hline \multicolumn{2}{|l|}{ Среднее } & 2,9 & 22301 & 64,0 & 118,2 & 7,5 & 11,3 & 18,7 & 8,0 \\
\hline \multicolumn{2}{|l|}{$\mathrm{HCP}_{05}$} & 0,9 & & & 5,1 & 1,14 & 0,54 & 1,48 & 1,1 \\
\hline \multirow{4}{*}{$3,0 \times 1,5$} & 40000 & 3,5 & 15284 & 33 & 118,3 & 3,9 & 7,8 & 19,4 & 7,7 \\
\hline & 50000 & 3,5 & 20355 & 46 & 131,4 & 6,0 & 12,1 & 20,2 & 7,1 \\
\hline & 60000 & 2,9 & 22754 & 49 & 111,8 & 5,5 & 11,0 & 19,3 & 7,4 \\
\hline & 70000 & 2,8 & 25493 & 53 & 105,3 & 5,6 & 11,2 & 18,3 & 8,7 \\
\hline \multicolumn{2}{|l|}{ Среднее } & 3,2 & 20972 & 45,3 & 116,6 & 5,3 & 10,5 & 19,3 & 7,7 \\
\hline \multicolumn{2}{|l|}{$\mathrm{HCP}_{05}$} & 0,8 & & & 9,5 & 0,6 & 0,33 & 1,36 & 1,28 \\
\hline \multirow{4}{*}{$3,0 \times 1,0$} & 40000 & 3,6 & 16368 & 22 & 111,7 & 2,6 & 8,1 & 19,1 & 7,7 \\
\hline & 50000 & 3,4 & 19664 & 30 & 125,0 & 3,8 & 11,7 & 19,1 & 8,3 \\
\hline & 60000 & 3,1 & 26198 & 36 & 107,7 & 3,9 & 11,6 & 18,3 & 7,8 \\
\hline & 70000 & 3,1 & 24920 & 36 & 103,5 & 3,7 & 11,2 & 19,4 & 8,0 \\
\hline \multicolumn{2}{|l|}{ Среднее } & 3,3 & 21788 & 31,0 & 112,0 & 3,4 & 10,4 & 19,0 & 8,0 \\
\hline \multicolumn{2}{|l|}{$\mathrm{HCP}_{05}$} & 0,6 & & & 9,23 & 0,41 & 0,20 & 1,04 & 0,70 \\
\hline
\end{tabular}


Вегетативная продуктивность сорта Молдова при применении обработок специальными удобрениями значительно превышала этот показатель у сорта Августин. Общее количество побегов на учетных кустах было выше в 1,4 раза, количество плодоносных побегов - в 1,3 раза, а количество соцветий - больше на $14,2 \%$.

Выявленные различия в биологической продуктивности позволяют охарактеризовать уровень адаптивности винограда данных сортов под действием обработок после перезимовки как более высокий.

В летний период, в условиях высоких температур воздуха и дефицита влаги, активность ростовых процессов у винограда сорта Мерло в связи с применением некорневых обработок значительно превышала значения этого показателя в контрольном варианте. К концу сентября прием обеспечивал формирование сильных доброкачественных побегов длиной 110-150 см, составляющих основу вегетационной массы кустов (рис. 4).

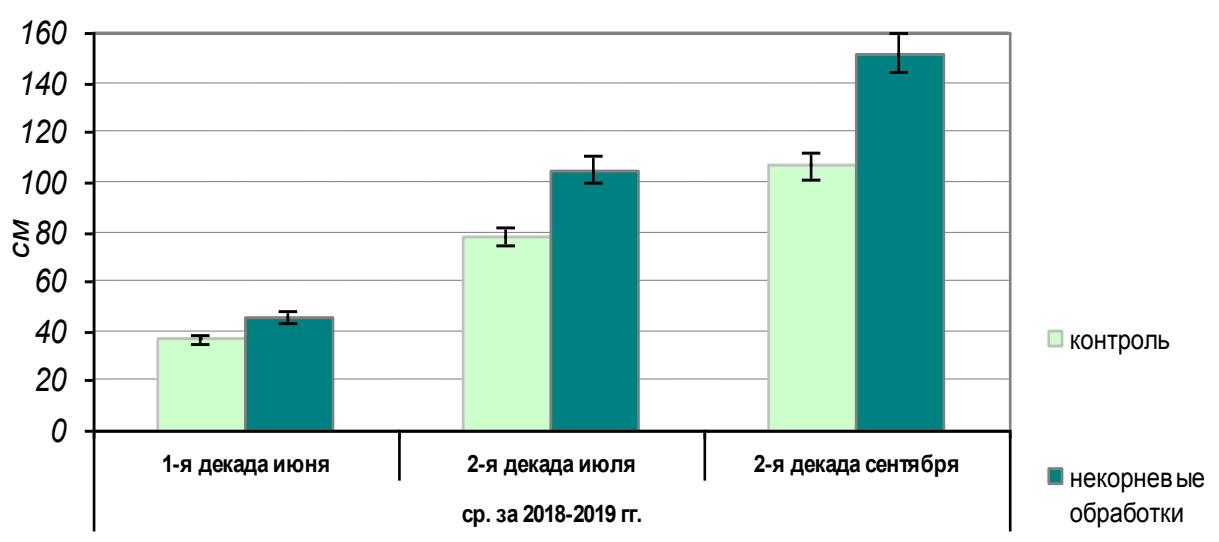

Рис. 4. Динамика роста побегов у растений винограда в среднем за 2018-2019 гг. в зависимости от применения некорневых обработок

В качестве основной критериальной оценки устойчивости растений к действию абиотических стрессоров рассматривали количество сформировавшихся соцветий и урожайность. У сорта Мерло при применении некорневых подкормок количество соцветий в среднем за 2016-2019 гг. было 50 шт./куст, на 9 \% больше по сравнению с контролем. У сорта Шардоне за 
2018-2019 гг. было 37 шт./куст, на 3 \% больше, чем на контрольных кустах, у сорта Августин на опытных и контрольных кустах количество соцветий было одинаково (24 шт./куст). О более высокой устойчивости растений винограда к стрессам летнего периода свидетельствует урожайность сорта Мерло на фоне применения удобрений. Преимущество некорневых подкормок растений винограда за длительный период наблюдений (2009-2019 гг.) составляет в среднем 7,3\% (рис. 5).

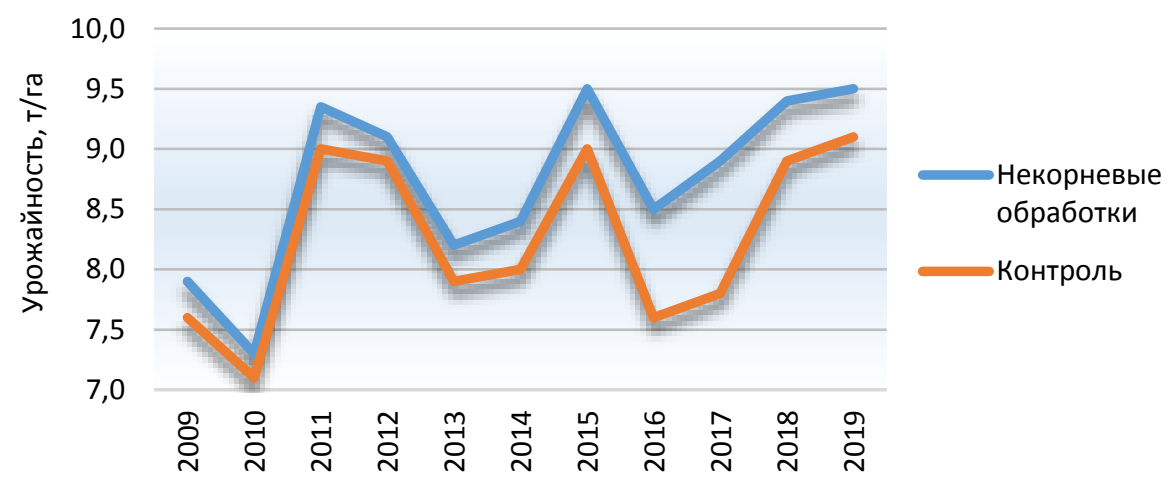

Рис. 5. Динамика изменения урожайности винограда в связи с применением некорневых подкормок, сорт Мерло

Многолетний экспериментальный материал позволил сформировать математически выраженную зависимость урожая винограда от минимальной температуры воздуха на фоне некорневых подкормок специальными удобрениями:

$$
\begin{array}{ll}
\text { в декабре } & \mathrm{y}=0,1532 \mathrm{x}+9,1504, \mathrm{r}=0,77 ; \\
\text { в январе } & \mathrm{y}=0,1475 \mathrm{x}+9,7894, r=0,84 ; \\
\text { в феврале } & \mathrm{y}=0,1331 \mathrm{x}+9,8938, \mathrm{r}=0,88
\end{array}
$$

Установлено сильное влияние препаратов некорневого действия Гумэл люкс, Филлотон, Агрумакс на повышение адаптивного потенциала виноградных растений сорта Шардоне (ООО «Возрождение») на бедных и каменистых почвах. Почва опытного участка в своем составе имела избыточное количество легкорастворимых токсичных солей. Повышение общей суммы солей отмечалось с глубины 60 см и составляло 0,3 \%, что является 
предельным для многолетних культур, с глубиной этот показатель возрастал, и на глубине 170 см достигал 1,8 \%. Тип засоления преимущественно хлоридно-сульфатный.

Концентрация ионов хлора по всему профилю (за исключением верхних 60 см) колебалось в пределах 1,00-1,13 мг-экв/100 г почвы. Кроме ионов хлора также отмечается повышенное содержание ионов магния с глубины 150 см. Несмотря на отрицательный солевой состав верхний горизонт почвы (0-60 см) имел благоприятные агрохимические свойства и достаточный уровень плодородия. Содержание гумуса составило 2,1 \%, вниз по профилю происходило снижение его содержания, что закономерно. Обеспеченность нитратным азотом составила 3,4 ; подвижным фосфором - 2,7; обменным калием - 49 мг/100 г почвы.

В качестве основной критериальной оценки адаптации растений винограда к засолению рассматривали динамику роста побегов и продуктивность. Различия в темпах роста лозы были отмечены во второй декаде июля (после второй обработки). Интенсивность ростовых процессов в вариантах с некорневыми подкормами была выше контроля. Статистически доказуемой средняя длина побегов оказалась при применении Агрумакса и Филлотона. Во второй декаде июля рост побегов замедлился во всех вариантах опыта (рис. 6).

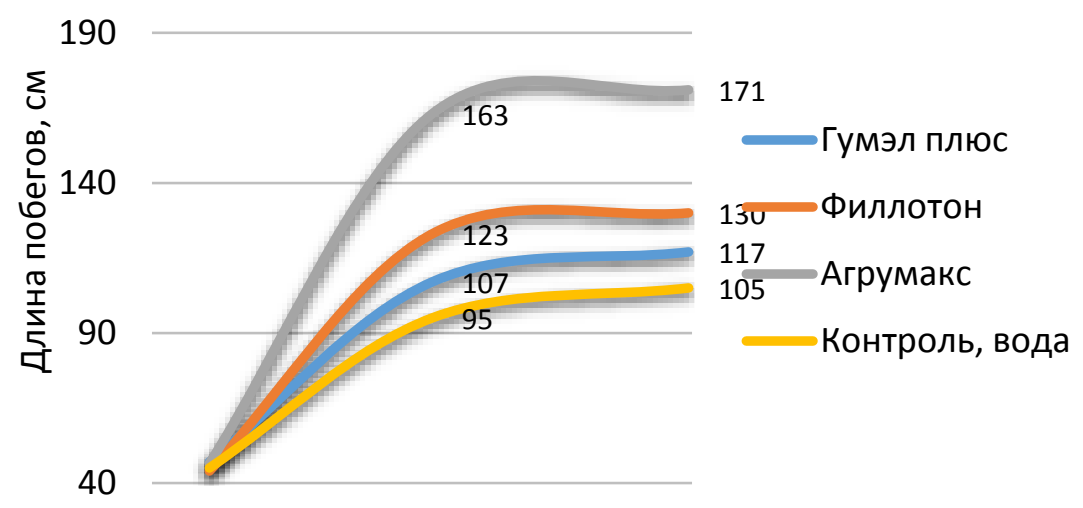

$\mathrm{HCP}_{05}=10,1(09.06 .19) \quad \mathrm{HCP}_{05}=12,8(12.07 .19) \quad \mathrm{HCP}_{05}=13,2(19.08 .19)$

Рис. 6. Динамика роста побегов у винограда сорта Шардоне в зависимости от применения некорневых обработок, 2019 г. 
Обработки кустов, произрастающих на условно пригодной почве, препаратами некорневого действия статистически доказуемо повысили урожайность и товарные качества винограда (табл. 5).

Таблица 5 - Урожайность и качественные показатели винограда на опытном участке, 2019 г.

\begin{tabular}{|c|c|c|c|c|}
\hline Вариант опыта & $\begin{array}{c}\text { Масcа } \\
\text { грозди, г }\end{array}$ & $\begin{array}{c}\text { Урожай } \\
\text { с куста, кг }\end{array}$ & $\begin{array}{c}\text { Сахаристость } \\
\Gamma / 100 \mathrm{~cm}^{3}\end{array}$ & $\begin{array}{c}\text { Кислотность, } \\
\text { г/дм }{ }^{3}\end{array}$ \\
\hline Гумэл плюс & 158 & 6,8 & 23 & 7,2 \\
\hline Филлотон & 167 & 8,1 & 22 & 6,9 \\
\hline Агрумакс & 183 & 9,2 & 23 & 7,2 \\
\hline Контроль, вода & 109 & 3,6 & 22,6 & 6,5 \\
\hline $\mathrm{HCP}_{05}$ & & 3,1 & & \\
\hline
\end{tabular}

Теоретической основой эффективного обеспечения эдафической устойчивости ампелоценозов является бездефицитный приток органики в почву, восстановление малого биологического круговорота и естественного процесса воспроизводства плодородия. Оздоровление почвы возможно с помощью различного вида агробиоремедиационных мероприятий, основанных на применении биопрепаратов, сорбентов, индукторов супрессивности или аккумуляторов загрязняющих веществ. Наилучшим образом эдафическая устойчивость контролируется при применении биологизированных способов содержания и обработки почвы - мульчирование органическим материалом, сидерация одно-двухлетними травами, длительное задернение многолетними видами трав.

К перспективному направлению восстановления деградируемой почвы ампелоценозов в качестве индукторов ее супрессивности в настоящих исследованиях были использованы биоудобрения вторичных отходов винодельческого производства. К основным вторичным отходам виноделия относится биоматериал после отжатия сока из свежего винограда или сусла 
Плодоводство и виноградарство Юга России № 66(6), 2020 г.

из перебродившей мезги. По многим показателям супрессивность почвы на промышленных виноградниках увеличивалась более всего при обогащении отходов дрожжевыми осадками.

Увеличилось содержание органического вещества на 0,3 \%, подвижных форм фосфора на 11,0 мг/кг, общего азота на 0,07 \%, макроэлементов кальция, натрия, магния, калия от 2,0 до 9,0 мг/кг. Гранулометрический состав почвы (фракция <0,01 мм) уменьшился на 0,7 \%. Внесение органического удобрения ускорило процесс деградации основных фоновых загрязнителей почвы. Концентрация токсичных веществ в почве хлорорганических препаратов уменьшилась на 25 \% (табл. 6).

Таблица 6 - Влияние внесения биоудобрения на физико-химический и механический состав почвы, сорт винограда Первенец Магарача, апрель 2019

\begin{tabular}{|c|c|c|c|c|c|c|}
\hline \multirow{2}{*}{$\begin{array}{c}\text { Показатели } \\
\text { (единицы } \\
\text { измерения) }\end{array}$} & \multicolumn{2}{|c|}{ Контроль } & \multicolumn{2}{|c|}{ Отходы виноделия } & \multicolumn{2}{|c|}{\begin{tabular}{|c} 
Отходы виноделия + \\
дрожжевые осадки
\end{tabular}} \\
\hline & апрель & октябрь & апрель & октябрь & апрель & октябрь \\
\hline pH водной вытяжки & $7,5 \pm 0,03$ & $7,6 \pm 0,03$ & $7,6 \pm 0,03$ & $7,6 \pm 0,03$ & $7,5 \pm 0,03$ & $7,6 \pm 0,03$ \\
\hline pH KCL & $6,1 \pm 0,05$ & $6,1 \pm 0,04$ & $6,2 \pm 0,05$ & $6,2 \pm 0,05$ & $6,2 \pm 0,05$ & $6,0 \pm 0,04$ \\
\hline $\begin{array}{l}\text { Сумма поглощенных } \\
\text { оснований, } \\
\text { ммоль } 100 \text { г }\end{array}$ & $25,6 \pm 0,41$ & $26,3 \pm 0,40$ & $26,9 \pm 0,64$ & $28,8 \pm 0,68$ & $27,6 \pm 0,77$ & $31,8 \pm 4,6$ \\
\hline Органическое в-во, \% & $3,3 \pm 0,13$ & $3,2 \pm 0,24$ & $3,5 \pm 0,14$ & $3,4 \pm 0,17$ & $3,6 \pm 0,11$ & $3,5 \pm 0,21$ \\
\hline $\begin{array}{l}\text { Плотный остаток } \\
\text { водной вытяжки } \\
\text { (сумма токсичных } \\
\text { солей) }\end{array}$ & $\begin{array}{c}<0,1(0,04) \% \\
400 \mathrm{мг} / \mathrm{к \Gamma}\end{array}$ & $\begin{array}{c}<0,1(0,04) \% \\
400 \text { мг/кг }\end{array}$ & $\begin{array}{c}<0,1(0,04) \% \\
400 \mathrm{мг} / к \Gamma\end{array}$ & $\begin{array}{c}<0,1(0,04) \% \\
400 \text { мг/кг }\end{array}$ & $\begin{array}{c}<0,1(0,04) \% \\
400 \mathrm{мг} / к \Gamma\end{array}$ & $\begin{array}{c}<0,1(0,04) \% \\
400 \text { мг/кг }\end{array}$ \\
\hline Общий азот, \% & $0,11 \pm 0,008$ & $0,09 \pm 0,01$ & $0,15 \pm 0,012$ & $0,14 \pm 0,013$ & $0,17 \pm 0,015$ & $0,16 \pm 0,012$ \\
\hline $\begin{array}{l}\text { Аммонийный азот, } \\
\text { мг/кг }\end{array}$ & $12,2 \pm 0,73$ & $12,0 \pm 0,69$ & $13,4 \pm 0,52$ & $14,2 \pm 0,48$ & $13,9 \pm 0,43$ & $17,2 \pm 1,8$ \\
\hline $\begin{array}{l}\text { Нитратный азот, } \\
\text { мг/кг }\end{array}$ & $36,2 \pm 0,61$ & $32,1 \pm 0,54$ & $35,1 \pm 0,55$ & $36,1 \pm 0,82$ & $34,4 \pm 0,84$ & $36,6 \pm 0,96$ \\
\hline Сульфат ион, мг/кг & $96 \pm 0,86$ & $87 \pm 0,79$ & $95 \pm 0,81$ & $96 \pm 0,88$ & $96 \pm 0,84$ & $96 \pm 0,84$ \\
\hline $\begin{array}{l}\text { Подвижный фосфор, } \\
\mathrm{P}_{2} \mathrm{O}_{5}, \text { мг/кг }\end{array}$ & $253 \pm 2,21$ & $250 \pm 1,44$ & $260 \pm 2,02$ & $258 \pm 1,28$ & $262 \pm 1,36$ & $262 \pm 37$ \\
\hline $\begin{array}{l}\text { Подвижный калий, } \\
\mathrm{K}_{2} \mathrm{O}, \text { мг/кг }\end{array}$ & $231 \pm 1,36$ & $230 \pm 1,26$ & $277 \pm 0,89$ & $270 \pm 0,76$ & $275 \pm 1,19$ & $253 \pm 0,97$ \\
\hline $\begin{array}{l}\text { Гранулометрический } \\
\text { состав почвы, <0,01 } \\
\text { мм, \% }\end{array}$ & $27,6 \pm 0,65$ & $27,9 \pm 0,70$ & $27,1 \pm 0,44$ & $26,7 \pm 0,35$ & $26,9 \pm 0,35$ & $26,1 \pm 0,48$ \\
\hline
\end{tabular}


Плодоводство и виноградарство Юга России № 66(6), 2020 г.

Управление устойчивостью растений винограда к филлоксере, продукционным процессом, качеством урожая и посадочного материала актуально применением физиологически активных соединений (ФАС). Изучение влияния ФАС на продуктивность плодоносящих насаждений винограда проводили на фоне сплошного заражения филлоксерой в многолетнем стационарном опыте на сорте Мускат дербентский. Изучали число сохранившихся кустов с начала закладки опыта, плодоносность кустов, средняя длина побега к началу цветения, урожай с куста, общий прирост опытных растений в конце вегетации.

Обработки опытных кустов проводились в течение 4 лет (2012-2015 гг.), а по достижении положительного эффекта от их применения, в течение последующих 4 лет (2016-2019 гг.), опытные растения не обрабатывались растворами ФАС. В вариантах применения ФАС к началу цветения растения имели больший вегетативный рост и длину побегов, что свидетельствует о лучшем физиологическом состоянии опытных кустов (табл. 7).

Таблица 7 - Весенний прирост побегов и плодоносность кустов, сорт Мускат Дербентский

\begin{tabular}{|c|c|c|c|c|c|c|c|c|}
\hline \multirow{3}{*}{ Варианты опыта } & \multicolumn{6}{|c|}{ Плодоносность кустов } & \multirow{2}{*}{\multicolumn{2}{|c|}{$\begin{array}{c}\text { Длина побега к } \\
\text { началу цветения, } \\
2019 \\
\end{array}$}} \\
\hline & \multicolumn{2}{|c|}{2017} & \multicolumn{2}{|c|}{2018} & \multicolumn{2}{|c|}{2019} & & \\
\hline & $\mathrm{K}_{1}$ & $\mathrm{~K}_{2}$ & $\mathrm{~K}_{1}$ & $\mathrm{~K}_{2}$ & $\mathrm{~K}_{1}$ & $\mathrm{~K}_{2}$ & $\mathrm{cM}$ & $\begin{array}{c}\% \\
\text { к контролю }\end{array}$ \\
\hline Контроль & 0,55 & 1,04 & 0,54 & 1,09 & 0,58 & 0,94 & 47,6 & 100 \\
\hline ЦАС40 мг/л & 0,90 & 1,13 & 0,53 & 1,11 & 0,87 & 1,25 & 62,1 & 131 \\
\hline НАС5 мг/л & 0,77 & 1,06 & 0,39 & 1,05 & 0,65 & 1,13 & 60,1 & 126 \\
\hline ЭАС50 мг/л & 0,62 & 1,13 & 0,53 & 1,08 & 0,84 & 1,23 & 56,6 & 119 \\
\hline ЦАС+НАС & 0,54 & 1,07 & 0,44 & 1,06 & 0,38 & 1,03 & 56,0 & 118 \\
\hline ЦАС+ЭАС & 0,78 & 1,11 & 0,77 & 1,16 & 0,95 & 1,27 & 61,0 & 128 \\
\hline ЦАС+НАС+ЭАС & 0,73 & 1,04 & 0,55 & 1,08 & 0,70 & 1,14 & 53,1 & 112 \\
\hline
\end{tabular}


Плодоводство и виноградарство Юга России № 66(6), 2020 г.

В контрольном варианте к осени 2019 г. сохранилось 4 куста из 10, тогда как в опытных вариантах с применением ФАС сохранилось 8-10 растений. Положительное влияние препаратов было зафиксировано в 2015-2018 гг. В последующем, в 2019 году, при отсутствии обработки растений положительный эффект последействия ФАС сохранился.

Во всех вариантах опыта с применением ФАС наблюдалось их положительное воздействие на увологические показатели винограда (табл. 8). Отмечаются более высокие показатели урожайности. Важно, что положительная динамика сохраняется и в последующие годы, без обработок растений (табл. 9).

Таблица 8 - Влияние ФАС на увологические показатели винограда, сорт Мускат дербентский, г. Дербент

\begin{tabular}{|c|c|c|c|c|c|c|c|c|c|c|c|c|c|}
\hline \multirow{3}{*}{ Вариант } & \multirow{2}{*}{\multicolumn{2}{|c|}{$\begin{array}{c}\text { Количе- } \\
\text { ство ягод, } \\
\text { шт./гроздь }\end{array}$}} & \multirow{2}{*}{\multicolumn{2}{|c|}{$\begin{array}{c}\text { Мacca } 100 \\
\text { ягод, Г }\end{array}$}} & \multirow{2}{*}{\multicolumn{2}{|c|}{$\begin{array}{c}\text { Масса } \\
\text { грозди, г }\end{array}$}} & \multicolumn{4}{|c|}{ Урожай } & \multirow{2}{*}{\multicolumn{2}{|c|}{$\begin{array}{c}\text { Массовая } \\
\text { концен- } \\
\text { трация } \\
\text { сахаров, } \\
\text { г/дм }^{3} \\
\end{array}$}} & \multirow{3}{*}{ 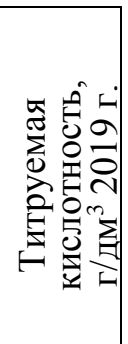 } \\
\hline & & & & & & & \multicolumn{2}{|c|}{ кг/куст } & \multicolumn{2}{|c|}{ т/га } & & & \\
\hline & $\begin{array}{l}\dot{\infty} \\
\dot{\infty}\end{array}$ & $\dot{\dot{a}}$ & $\stackrel{\dot{\infty}}{\stackrel{\infty}{\sigma}}$ & $\stackrel{\dot{a}}{\stackrel{\vec{N}}{\partial}}$ & $\stackrel{\dot{\infty}}{\stackrel{\infty}{\ddot{~}}}$ & $\dot{\vec{a}}$ & $\stackrel{\dot{\infty}}{\stackrel{\infty}{\circ}}$ & $\dot{\dot{a}}$ & $\stackrel{\dot{\infty}}{\dot{\infty}}$ & $\stackrel{\dot{a}}{\dot{\Xi}}$ & $\begin{array}{l}\dot{\dot{\infty}} \\
\stackrel{\infty}{\circ}\end{array}$ & $\dot{\vec{\sigma}}$ & \\
\hline Контроль & 79 & 42 & 256 & 397 & 202 & 183 & 3,3 & 3,4 & 4,7 & 4,7 & 177 & 197 & 5,3 \\
\hline ЦАС 40 мг/л & 88 & 137 & 297 & 359 & 261 & 523 & 7,1 & 34,0 & 10,1 & 48,4 & 190 & 186 & 6,2 \\
\hline НАС 5 мг/л & 71 & 130 & 239 & 357 & 170 & 519 & 4,3 & 29,6 & 6,1 & 42,1 & 194 & 196 & 6,8 \\
\hline ЭАС 50 мг/л & 76 & 84 & 234 & 328 & 194 & 288 & 5,6 & 15,8 & 8,0 & 22,5 & 199 & 199 & 5,1 \\
\hline ЦАС+HAC & 62 & 86 & 210 & 358 & 130 & 328 & 2,6 & 5,9 & 3,7 & 8,4 & 198 & 204 & 6,2 \\
\hline ЦАС+ЭАС & 113 & 117 & 345 & 327 & 389 & 406 & 13,0 & 25,6 & 18,6 & 36,5 & 200 & 187 & 6,3 \\
\hline ЦАС +НАС+ЭАС & 85 & 110 & 260 & 393 & 221 & 446 & 5,4 & 16,5 & 7,7 & 23,5 & 200 & 196 & 6,1 \\
\hline HCP 05 & & & & & & & 1,1 & 1,4 & & & & & \\
\hline
\end{tabular}

Таблица 9 - Урожай винограда при применении ФАС, сорт Мускат дербентский, 2013-2019 гг.

\begin{tabular}{|l|c|c|}
\hline \multirow{2}{*}{ Вариант } & \multicolumn{2}{|c|}{ Урожай } \\
\cline { 2 - 3 } & кг/куст & $\%$ \\
\hline Контроль & 6,9 & 100 \\
\hline ЦАС 40 мг/л & 15,9 & 231 \\
\hline НАС 5 мГ/л & 12,7 & 184 \\
\hline ЭАС 50 мг/л & 13,6 & 197 \\
\hline ЦАС+НАС & 6,9 & 100 \\
\hline ЦАС+ЭАС & 15,5 & 225 \\
\hline ЦАС+НАС+ЭАС & 10,9 & 158 \\
\hline
\end{tabular}


Таким образом, применение ФАС различного механизма действия позволяет корнесобственным растениям восприимчивого к корневой филлоксере сорта Мускат дербентский противостоять вредителю и реализовать генетический потенциал на фоне заражения.

Bbыводы. На основе результатов длительных исследований на промышленных виноградниках юга России предложены методы эффективного управления устойчивостью ампелоценозов в условиях антропогенной интенсификации производства и изменений климата. Для устойчивого виноградарства в Краснодарском крае выделено 5 агроэкологических зон и 47 подзон с использованием цифровых почвенных карт, карт изотерм и изогиет. Каждая подзона характеризуется однородностью территории и является основой для формирования терруаров, оптимизациии зонально ориентированного сортимента и агротехнологий.

Оптимизированны схемы и плотности посадки кустов винограда, их нагрузки побегами на примере сорта Рислинг рейнский; режимы некорневого питания растений микроэлементами в сочетании с биологически активными компонентами; обоснованы биологизированные технологии обратимости деградационных изменений почвы ампелоценозов на основе энергетического биоматериала; методы управления устойчивостью корнесобственных виноградников к корневой филлоксере на основе использования физиологически активных соединений.

Установлено положительное влияние предлагаемых методов на эффективное использование возобновляемых природных ресурсов в продукционном процессе растений винограда, повышение уровня реализации потенциала его хозяйственной продуктивности и улучшение качества винопродукции, а также на адаптивную, продукционную, экологическую и эдафическую устойчивость ампелоценозов. 


\section{Литература}

1. Luo G., Wu X., Leng P. Study on climatic zoning for wine-grape growing in Huabei Regions // Acta hortic. sinica. 2001. Vol. 28, № 6. P. 487 - 496.

2. Carte des sols viticoles genevois: vers une utilization pratique / S. Burgos, N. Dakhel, M. Docourt, J.-J. Schwarz // Rev. Suisse Vitic. Arboric. Hortic. 2008. Vol. 40, № 4. P. $215-221$.

3. Penkov M., Roytchev V., Bambalov V. Influence of Groving Location on the Quality of Grape and Wines from Various Vine Cultivars // Почвознан. Агрохим. Екол. 2007. Vol. 42, № 4. P. 44 - 53.

4. Петров В.С., Алейникова Г.Ю., Наумова Л.Г., Лукьянова А.А. Адаптивна реакция на лозови сортове в условия на климатични промени // Лозарство и винарство. 2018. №6. C. 18-31.

5. Алейникова Г.Ю., Петров В.С., Соколова В.В. Тенденции локального изменения климата и их влияние на продуктивность и фенологию винограда // Научные труды СКФНЦСВВ, 2019. Т. 23. С. 117-125.

6. Монин А.С., Сонечкин Д.М. Колебания климата по данным наблюдений: тройной солнечный и другие циклы. М.: Наука, 2005. 192 с.

7. Изменения температуры в тропо-стратосфере Северного полушария во второй половине ХХ столетия / Ю.П. Переведенцев [и др.] // Мировой океан, водоемы суши и климат: Тр.ХІІ съезда Русского геогр. об-ва. СПб., 2005. Т. 5. С. 361-365.

8. Агробиологические, физиолого-биохимические и технологические особенности винограда сорта Рислинг рейнский в условиях изменяющегося климата юга России / В.С. Петров [и др.] // «Магарач». Виноградарство и виноделие. 2019. 21(3). С. 204-210.

9. Schoedl K., Schuhmacher R., Forneck A. Correlating physiological parameters with biomarkers for UV-B stress indicators in leaves of grapevine cultivars Pinot noir and Riesling // J. Agric. Sci. 2013. Vol. 151. P. 189-200.

10. Lovisolo C., Perrone I., Carra A., Ferrandino A., Flexas J., Medrano H., Schubert A. Drought-induced changes in development and function of grapevine (Vitis spp.) organs and in their hydraulic and non-hydraulic interactions at the whole-plant level: a physiological and molecular update // Funct. Plant Biol. 2010. Vol. 37. P. 98-116.

11. Leolini L., Bregaglio S., Moriondo M., Ramos M.C., Bindia M., Ginaldi F. A model library to simulate grapevine growth and development: software implementation, sensitivity analysis and field level application // European Journal of Agronomy. 2018. Vol. 99. P. 92-105.

12. Модонкаева А.Э., Ермолина Г.В., Капустина Е.В. Внекорневые обработки и качество винограда // Виноград. Вино. 2010. № 6. С. 18.

13. Влияние новых микроудобрений на урожай и качестве винограда сорта Шардоне и виноматериалов из него / А.А. Красильников [и др.] // Виноделие и виноградарство. 2011. № 4. C. $42-43$.

14. Регулирование урожая и качества винограда сорта Рислинг путем использования различных технологических схем некорневой подкормки Нутривантом плюс / П.П. Радчевский [и др.] // Политематический сетевой электронный научный журнал Кубанского государственного аграрного университета, [Электронный ресурс]. 2017. № 125. - C. 658-679.

15. Rahim N., Hoda N., Sasan R., Moslem D. Effect of foliar application of boron and zinc on qualitative and quantitative fruit characteristic of grape vine // International Journal of 
Agriculture and Crop Sciences [Электронный ресурс] - London, 2013. Vol 6, № 9. C. 485-492.

16. Аннаби М., Хуот С., Пуатрено М., Рэмпон Ж.Н., Гайар Х., Ле Биссонн Я. Влияние органических поправок на стабильность агрегатов почвы // Устойчивое управление органическими отходами для защиты окружающей среды и безопасности пищевых продуктов. Рамиран, 2004. № 1. С. 51-54.

17. Егоров Е.А., Воробьева Т.Н., Ветер Ю.А. Повышение биогенности почвы виноградников применением отходов виноделия // Вестник АПК Ставрополья. 2015. № 2 (18). C. 171-174.

18. Петров В.С. Потенциал хозяйственной продуктивности винограда, его реализация в условиях умеренно континентального климата юга России // «Магарач». Виноградарство и виноделие. 2016. № 1. С. 20 - 22.

19. Комарек М., Cadkova, Е., Храстный, B., Bordas, F., Bollinger J-C. Загрязнение почв виноградников фунгицидами: обзор экологических и токсикологических аспектов // Environment International. 2010. Vol. 36. C. 138 - 151.

20. Бермудес-Кузо А., Ариас-Эстевес М., Новоа-Муньос J.С., Lopez-Periago Е., Soto Gonzalez B., Simal-Gandara J. Сезонные распределения фунгицидов в почвах и отложениях небольшого речного бассейна, частично отведенного под виноградники // Исследование воды. 2007. Т. 41. С. 4515-4525.

21. Тихонович И.А., Проворов Н.А. Симбиозы растений и микроорганизмов: молекулярная генетика агросистем. СПб.: Изд-во С.-Петербургского университета. 2009. $210 \mathrm{c}$.

22. Arvanitoyannis I.S., Ladas D., Mavromatis, A. Возможное использование и применение обработанных отходов вина: обзор // Международный журнал по пищевой науке и технике. 2006. Т. 41. С. 475-487.

23. Deinlein U., Stephan A.B., Horie T. et al. Plant salttolerance mechanisms // Trends Plant Sci. 2014. Vol. 19. P. 371-379.

24. Новикова А.Ф., Панкова Е.И., Контобойцева А.А. Зональные, провинциальные и литолого-геомрфологические особенности проявления засоленности почв в Южном федеральном округе России // Почвоведение. 2011. №8. С. 923-939.

25. Maser P., Eckelman B., Vaidyanathan R. et al. Altered shoot/root Na+ distribution and bifurcating salt sensitivity in Arabidopsis by genetic disruption of the $\mathrm{Na}+$ transporter AtHKT1 // FEBS Lett. 2002. Vol. 531. P. 157-161.

26. Munns R., Tester M. Mechanisms of salinity tolerance // Annu. Rev. Plant Biol. 2008. Vol. 59. P. 651-681.

27. Попова В.Ф. Черников Е.А. Влияние рельефа и климатических условий на трансформацию солей в почве виноградников Юга Тамани // Научные труды СКФНЦСВВ. Т. 15. Краснодар: СКФНЦСВВ, 2018. С. 57-62.

28. Зубкова Н.Ф. Цитодеф - регулятор роста растений цитокининового действия // Регуляторы роста и развития в биотехнологиях: тезисы докл. VI Междунар. конф.. M., 2001. C. 94.

29. Дрожжина Н.А., Гурова А.И., Максименко Л.В., Башкиров А.А. К оценке экологической безопасности пестицидов ряда фенилмочевин при применении в сельском хозяйстве // Вестник РУДН, Сер. Экология и безопасность жизнедеятельности. 2004. №1(10). C. 47-53. 


\section{References}

1. Luo G., Wu X., Leng P. Study on climatic zoning for wine-grape growing in Huabei Regions // Acta hortic. sinica. 2001. Vol. 28, № 6. R. 487 - 496.

2. Carte des sols viticoles genevois: vers une utilization pratique / S. Burgos, N. Dakhel, M. Docourt, J.-J. Schwarz // Rev. Suisse Vitic. Arboric. Hortic. 2008. Vol. 40, № 4. R. $215-221$.

3. Penkov M., Roytchev V., Bambalov V. Influence of Groving Location on the Quality of Grape and Wines from Various Vine Cultivars // Pochvoznan. Agrohim. Ekol. 2007. Vol. 42, № 4. R. 44 - 53.

4. Petrov V.S., Alejnikova G.Yu., Naumova L.G., Luk'yanova A.A. Adaptivna reakciya na lozovi sortove v usloviya na klimatichni promeni // Lozarstvo i vinarstvo. 2018. №6. S. 18-31.

5. Alejnikova G.Yu., Petrov V.S., Sokolova V.V. Tendencii lokal'nogo izmeneniya klimata i ih vliyanie na produktivnost' i fenologiyu vinograda // Nauchnye trudy SKFNCSVV, 2019. T. 23. S. 117-125.

6. Monin A.S., Sonechkin D.M. Kolebaniya klimata po dannym nablyudenij: trojnoj solnechnyj i drugie cikly. M.: Nauka, 2005. 192 s.

7. Izmeneniya temperatury $\mathrm{v}$ tropo-stratosfere Severnogo polushariya vo vtoroj polovine XX stoletiya / Yu.P. Perevedencev [i dr.] // Mirovoj okean, vodoemy sushi i klimat: Tr.XII s"ezda Russkogo geogr. ob-va. SPb., 2005. T. 5. S. 361-365.

8. Agrobiologicheskie, fiziologo-biohimicheskie i tekhnologiche-skie osobennosti vinograda sorta Risling rejnskij $\mathrm{v}$ usloviyah izmenyayushchegosya klimata yuga Rossii / V.S. Petrov [i dr.] // «Magarach». Vinogradarstvo i vinodelie. 2019. 21(3). C. 204-210.

9. Schoedl K., Schuhmacher R., Forneck A. Correlating physiologi-cal parameters with biomarkers for UV-B stress indicators in leaves of grapevine cultivars Pinot noir and Riesling // J. Agric. Sci. 2013. Vol. 151. P. 189-200.

10. Lovisolo C., Perrone I., Carra A., Ferrandino A., Flexas J., Medrano H., Schubert A. Drought-induced changes in development and function of grapevine (Vitis spp.) organs and in their hydraulic and non-hydraulic interactions at the whole-plant level: a physiological and molecular update // Funct. Plant Biol. 2010. Vol. 37. P. 98-116.

11. Leolini L., Bregaglio S., Moriondo M., Ramos M.C., Bindia M., Ginaldi F. A model library to simulate grapevine growth and development: software implementation, sensitivity analysis and field level application // European Journal of Agronomy. 2018. Vol. 99. P. 92-105.

12. Modonkaeva A.E., Ermolina G.V., Kapustina E.V. Vnekornevye obrabotki i kachestvo vinograda // Vinograd. Vino. 2010. № 6. S. 18.

13. Vliyanie novyh mikroudobrenij na urozhaj i kachestve vinograda sorta Shardone i vinomaterialov iz nego / A.A. Krasil'nikov [i dr.] // Vinodelie i vinogradarstvo. 2011. № 4. S. $42-43$.

14. Regulirovanie urozhaya i kachestva vinograda sorta Risling pu-tem ispol'zovaniya razlichnyh tekhnologicheskih skhem nekornevoj pod-kormki Nutrivantom plyus / P.P. Radchevskij [i dr.] // Politematicheskij setevoj elektronnyj nauchnyj zhurnal Kubanskogo gosudarstvennogo ag-rarnogo universiteta, [Elektronnyj resurs]. 2017. № 125. - S. 658-679.

15. Rahim N., Hoda N., Sasan R., Moslem D. Effect of foliar applica-tion of boron and zinc on qualitative and quantitative fruit characteristic of grape vine // International Journal of Agriculture and Crop Sciences [Elektronnyj resurs] - London, 2013. Vol 6, №9. S. 485-492. 
16. Annabi M., Huot S., Puatreno M., Rempon Zh.N., Gajar H., Le Bissonn Ya. Vliyanie organicheskih popravok na stabil'nost' agregatov pochvy // Ustojchivoe upravlenie organicheskimi othodami dlya zashchity okruzhayushchej sredy i bezopasnosti pishchevyh produktov. Ramiran, 2004. № 1. S. 51-54.

17. Egorov E.A., Vorob'eva T.N., Veter Yu.A. Povyshenie biogen-nosti pochvy vinogradnikov primeneniem othodov vinodeliya // Vestnik APK Stavropol'ya. 2015. №2 (18). S. 171-174.

18. Petrov V.S. Potencial hozyajstvennoj produktivnosti vino-grada, ego realizaciya $\mathrm{v}$ usloviyah umerenno kontinental'nogo klimata yuga Rossii // «Magarach». Vinogradarstvo i vinodelie. 2016. № 1. S. 20 - 22.

19. Komarek M., Cadkova, E., Hrastnyj, V., Bordas, F., Bollinger J-C. Zagryaznenie pochv vinogradnikov fungicidami: obzor ekologicheskih i toksikologicheskih aspektov // Environment International. 2010. Vol. 36. S. 138 - 151.

20. Bermudes-Kuzo A., Arias-Esteves M., Novoa-Mun'os J.C., Lopez-Periago E., SotoGonzalez B., Simal-Gandara J. Sezonnye rasprede-leniya fungicidov v pochvah i otlozheniyah nebol'shogo rechnogo bassejna, chastichno otvedennogo pod vinogradniki // Issledovanie vody. 2007. T. 41. S. 4515-4525.

21. Tihonovich I.A., Provorov N.A. Simbiozy rastenij i mikro-organizmov: molekulyarnaya genetika agrosistem. SPb.: Izd-vo S.-Peterburgskogo universiteta. 2009. $210 \mathrm{~s}$.

22. Arvanitoyannis I.S., Ladas D., Mavromatis, A. Vozmozhnoe is-pol'zovanie i primenenie obrabotannyh othodov vina: obzor // Mezh-dunarodnyj zhurnal po pishchevoj nauke i tekhnike. 2006. T. 41. S. 475-487.

23. Deinlein U., Stephan A.B., Horie T. et al. Plant salttolerance mechanisms // Trends Plant Sci. 2014. Vol. 19. P. 371-379.

24. Novikova A.F., Pankova E.I., Kontobojceva A.A. Zonal'nye, provincial'nye i litologo-geomrfologicheskie osobennosti proyavle-niya zasolennosti pochv v Yuzhnom federal'nom okruge Rossii // Pochvo-vedenie. 2011. №8. S. 923-939.

25. Maser P., Eckelman B., Vaidyanathan R. et al. Altered shoot/root Na+ distribution and bifurcating salt sensitivity in Arabidopsis by genetic disruption of the $\mathrm{Na}+$ transporter AtHKT1 // FEBS Lett. 2002. Vol. 531. P. 157-161.

26. Munns R., Tester M. Mechanisms of salinity tolerance // Annu. Rev. Plant Biol. 2008. Vol. 59. P. 651-681.

27. Popova V.F. Chernikov E.A. Vliyanie rel'efa i klimaticheskih uslovij na transformaciyu solej v pochve vinogradnikov Yuga Tamani // Nauchnye trudy SKFNCSVV. T. 15. Krasnodar: SKFNCSVV, 2018. S. 57-62.

28. Zubkova N.F. Citodef - regulyator rosta rastenij citokini-novogo dejstviya // Regulyatory rosta i razvitiya v biotekhnologiyah: tezi-sy dokl. VI Mezhdunar. konf.. M., 2001. S. 94.

29. Drozhzhina N.A., Gurova A.I., Maksimenko L.V., Bashkirov A.A. K ocenke ekologicheskoj bezopasnosti pesticidov ryada fenilmoche-vin pri primenenii v sel'skom hozyajstve // Vestnik RUDN, Ser. Ekolo-giya i bezopasnost' zhiznedeyatel'nosti. 2004. №1(10). S. 47-53. 